\title{
Heavy Metal Distribution and Groundwater Quality Assessment for a Coastal Area on a Chinese Island
}

\author{
Sha Lou ${ }^{1}$, Shuguang Liu ${ }^{1,2 *}$, Chaomeng Dai ${ }^{1}$, An Tao ${ }^{1}$, Bo Tan $^{1}$, Gangfeng Ma ${ }^{3}$, \\ Roman Sergeeyvich Chalov ${ }^{4}$, Sergey Romanovich Chalov ${ }^{4}$ \\ 'Department of Hydraulic Engineering, Tongji University, \\ No.1239 Siping Road, Shanghai 200092, China \\ ${ }^{2}$ Key Laboratory of Yangtze River Water Environment, Ministry of Education, \\ Tongji University, No. 1239 Siping Road, Shanghai 200092, China \\ ${ }^{3}$ Department of Civil and Environmental Engineering, Old Dominion University, \\ 1000 Rollins Hall, Norfolk, VA 23529, USA \\ ${ }^{4}$ Faculty of Geography, Lomonosov Moscow State University, \\ GSP-1, 1 Leninskiye Gory, Moscow, 119991, Russia
}

Received: 5 September 2016

Accepted: 13 November 2016

\begin{abstract}
Chongming Island is located in the lower Yangtze Estuary in China. Due to the Leachate from a refuse landfill and the hydrodynamics of the Yangtze Estuary, the groundwater environment is particularly complicated on Chongming Island. Field observations were carried out around the landfill disposal site. The groundwater table, temperature, $\mathrm{pH}$, salinity, and dissolved oxygen were measured in the field by portable equipment, and 192 water samples were collected at eight groundwater sites and one surface water site. Through laboratory analysis we found the highest measured concentration of $\mathrm{Cr}$ to be $54.07 \mu \mathrm{g} / \mathrm{L}$, and the measured concentration of $\mathrm{Zn}$ was in the range of $8 \mu \mathrm{g} / \mathrm{L}$ to more than $200 \mu \mathrm{g} / \mathrm{L}$, which were both higher than their background values. Strong correlations were found between the heavy metal $(\mathrm{Cr}, \mathrm{Ni}, \mathrm{Cu})$ concentrations and physico-chemical characteristics (salinity and $\mathrm{pH}$ ), which indicated that both the landfill and the tides played an important role in the distribution of heavy metal concentrations. Both the HPI and PoS Indices were greater than their critical values near the disposal site, indicating groundwater pollution by heavy metals. We show that $\mathrm{Cr}$ and $\mathrm{Ni}$ are the major heavy metals causing groundwater contamination in the study region.
\end{abstract}

Keywords: groundwater quality, heavy metals, correlation analysis, pollution-index method

\footnotetext{
*e-mail: liusgliu@tongji.edu.cn
} 


\section{Introduction}

As a vital component of the eco-environment and water resource systems, groundwater is important for both the global hydrological cycle and the water supply [1]. However, contamination of groundwater has become a serious problem for the entire world. Groundwater quality has deteriorated in many countries, including India, Korea, Greece, America, and China [2]. Due to the increased human population and anthropogenic activities, the quality of groundwater, especially shallow groundwater, is greatly threatened. The leaks or spills from landfills, manufacturing facilities, and agricultural sites are potential sources of groundwater pollution. Because the remediation of the groundwater environment is an expensive and time-consuming process, the precise evaluation of groundwater quality characteristics and the assessment of potential pollution sources are essential to prevent groundwater pollution or increase the efficiency of remediation.

Heavy metal contaminants such as chromium $(\mathrm{Cr})$, nickel $(\mathrm{Ni})$, copper $(\mathrm{Cu})$, zinc $(\mathrm{Zn})$, cadmium $(\mathrm{Cd})$, and lead $(\mathrm{Pb})$ are generally more persistent than organic contaminants. They can be mobile in soils and leach into aquifers. A fraction of heavy metal contaminants may lead to severe poisoning if they pollute the groundwater that is used for drinking or irrigation purposes. Field observations have been conducted in a great number of studies to investigate heavy metal pollution in groundwater. For instance, Economou-Eliopoulos et al. [3] analyzed groundwater samples collected from domestic and irrigation wells to investigate the long-term leaching responses of chromium under atmospheric conditions in central Euboea, Greece. Through sampling in the vicinity of a landfill site [4], the association of heavy metal ions to colloids was discussed in Bavaria, Germany. In Asia, Muhammad et al. [5] collected water samples in northern Pakistan to investigate the heavy metal concentrations in groundwater. Phan et al. [6] collected groundwater samples from three provinces in the Mekong River basin of Cambodia to study the potential contamination from heavy metals in shallow Cambodian groundwater. Leung et al. [7] discussed the heavy metal distributions in groundwater samples collected from natural slopes and urbanized spaces in the mid-level area of Hong Kong, China, and investigated the impact of urbanization on the aqueous distributions of these chemicals. Field observation is a useful method for studying heavy metal pollution in groundwater. It can provide basic data and information for understanding the groundwater pollution extent and effectively assess the level of heavy metal pollution. Based on the measured data, the impact factors of groundwater pollution and the dynamic mechanism of heavy metal transport in groundwater could be further analyzed [8-10].

Several approaches have been proposed to evaluate groundwater quality after field observation. Devic et al. [11] utilized the cluster analysis method for groundwater quality assessment, which classifies data into several groups according to the features of the data and the natural background values. Masoud [12] applied the factor analysis method to assess groundwater quality in the shallow aquifers in the western Nile Delta. In this method, principal components were computed from a covariance or other cross-product matrix describing the dispersion of the multiple measured interrelated variables. Both the cluster analysis and factor analysis methods need a large amount of data, and the results rely greatly on the optimal selection of variables. The fuzzy membership function was utilized for assessing groundwater quality by Zhang et al. [13]. Although fuzzy sets and fuzzy optimization could provide a useful technique to address the imprecision in the objectives and water quality standards, the subjective factor plays an important role in the choice of classes and fuzzy memberships of the indicators. Several pollution indices have also been developed to evaluate groundwater quality, including the DRASTIC groundwater vulnerability index [14], the WQI index [15], the modified DWQI index [16], the GWQI index [17], and the limit-risk index [18]. Compared with the above-described methods, the pollution-index method is relatively easy to implement and requires a small amount of data. According to our field observations, the combination of the heavy metal
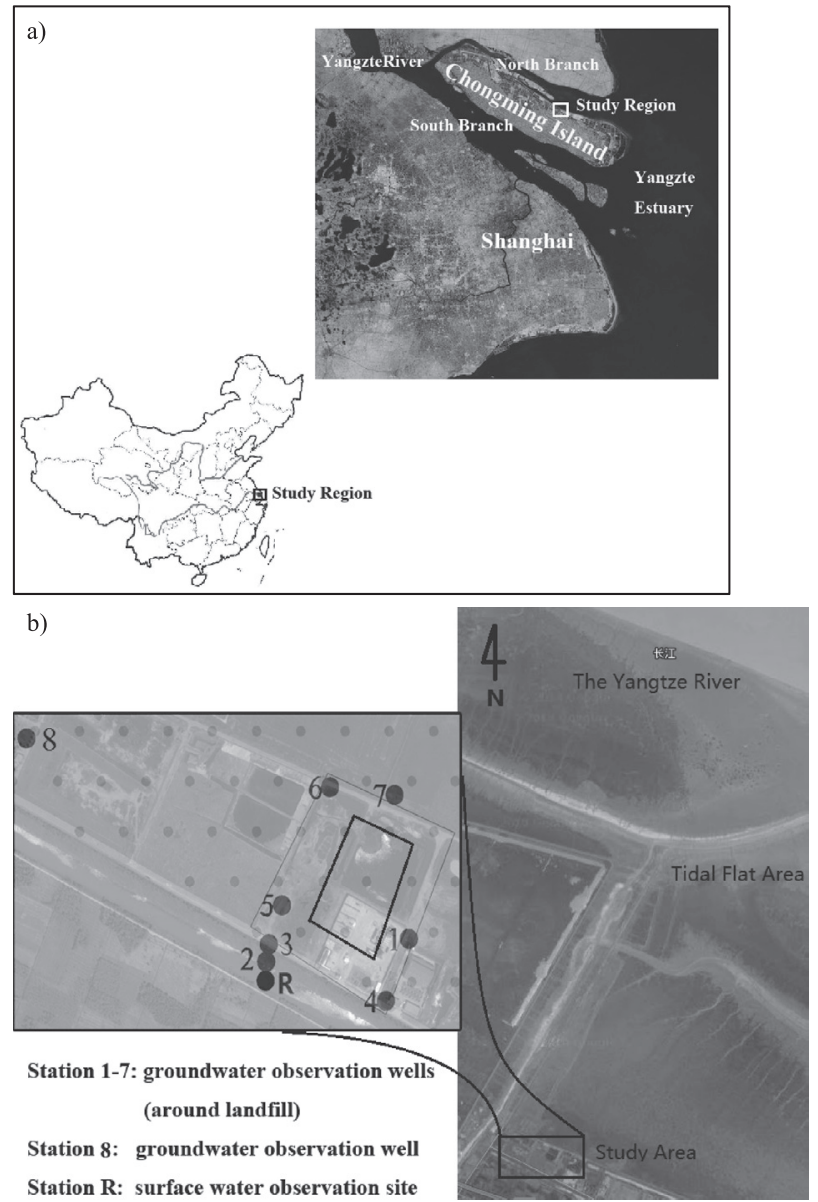

Fig. 1. Study area: a) location of study region; b) observation sites based on Google Maps (landfill area is inside the irregular quadrilateral marked by a black line). 
pollutant Index (HPI) [19] - involving $\mathrm{Cr}, \mathrm{Cu}, \mathrm{Zn}, \mathrm{Cd}$, and $\mathrm{Pb}$ - and the PoS Index [20] - involving $\mathrm{Cr}, \mathrm{Ni}, \mathrm{Cd}$, and $\mathrm{Pb}$ - were utilized to synthetically assess the groundwater quality caused by heavy metal pollution.

In this study, field observations were carried out to collect hydro-geological and hydro-chemical information in the shallow aquifer underneath and around a landfill site on Chongming Island, China. Water samples were collected from eight groundwater wells and one surface water site in March 2014, which is a typical dry season. The pollution-index methods were proposed to assess groundwater quality. The objectives of this paper are to investigate the distribution of heavy metal pollution in the groundwater around the landfill, understand the potential impacts of coastal hydrodynamics and leachate percolation on groundwater quality, and assess groundwater quality to protect groundwater from further contamination. Results in this paper could be beneficial for the protection and management of water resources and the aquatic environment. The method used in this study could provide some guidance for the management of groundwater resources in similar coastal areas and serve as a good example for groundwater quality assessment.

\section{Materials and Methods}

\section{Study Area Description}

Chongming Island in Shanghai, China, is located in the lower Yangtze Estuary with an area of about $1,200 \mathrm{~km}^{2}$. It is the third largest island in China and the largest alluvial island in the world. In 2005 the "General Plan of Chongming Island" (2006-20) was enacted by the Shanghai Government. This document presented the goal that Chongming Island would be a world-class ecological island along the West Pacific Region by 2020. However, there is a refuse landfill in the northern part of the island to deal with domestic waste. The landfill leachate may leach into the aquifer and affect groundwater quality. Under the combined impacts of groundwater motion and the coastal

Table 1. Locations of observation sites.

\begin{tabular}{|c|c|c|}
\hline Station & \multicolumn{2}{|c|}{ Locations } \\
\hline 1 & $31^{\circ} 38^{\prime} 6.30^{\prime \prime} \mathrm{N}$ & $121^{\circ} 41^{\prime} 41.42^{\prime \prime} \mathrm{E}$ \\
\hline 2 & $31^{\circ} 38^{\prime} 5.51^{\prime \prime} \mathrm{N}$ & $121^{\circ} 41^{\prime} 32.09$ ” E \\
\hline 3 & $31^{\circ} 38^{\prime} 5.93^{\prime \prime} \mathrm{N}$ & $121^{\circ} 41^{\prime} 32.30^{\prime \prime} \mathrm{E}$ \\
\hline 4 & $31^{\circ} 38^{\prime} 3.35^{\prime \prime} \mathrm{N}$ & $121^{\circ} 41^{\prime} 40.07^{\prime \prime} \mathrm{E}$ \\
\hline 5 & $31^{\circ} 38^{\prime} 8.64^{\prime \prime} \mathrm{N}$ & $121^{\circ} 41^{\prime} 33.81^{\prime \prime} \mathrm{E}$ \\
\hline 6 & $31^{\circ} 38^{\prime} 13.95^{\prime \prime} \mathrm{E}$ & $121^{\circ} 41^{\prime} 36.82^{\prime \prime} \mathrm{N}$ \\
\hline 7 & $31^{\circ} 38^{\prime} 12.50^{\prime \prime} \mathrm{N}$ & $121^{\circ} 41^{\prime} 42.45^{\prime \prime} \mathrm{E}$ \\
\hline 8 & $31^{\circ} 38^{\prime} 15.69^{\prime \prime} \mathrm{N}$ & $121^{\circ} 41^{\prime} 15.45^{\prime \prime} \mathrm{E}$ \\
\hline $\mathrm{R}$ & \multicolumn{2}{|c|}{$\begin{array}{l}\text { surface water observation site } \\
\quad(2 \mathrm{~m} \text { near Station } 2)\end{array}$} \\
\hline
\end{tabular}

hydrodynamics of the Yangtze Estuary, the environment of groundwater is extremely complicated on Chongming Island, which significantly increases the difficulties for groundwater quality assessment.

The study region is located in the northern coastal area of Chongming Island (Fig. 1a). It is approximately $720 \mathrm{~m}$ long and $250 \mathrm{~m}$ wide, occupying a total area of $1.8 \times 10^{5} \mathrm{~m}^{2}$. It borders on the tidal flat in the northern branch of the Yangtze Estuary. The area of the landfill site is approximately $2.64 \times 10^{4} \mathrm{~m}^{2}$. There are seven groundwater observation wells (Stations 1-7) around the landfill, one groundwater observation well (Station 8) that is approximately $500 \mathrm{~m}$ away from the landfill, and one surface water observation site (Station R) located at a stream on the southwest side of the landfill. The distribution of observation stations is shown in Fig. $1 b$. Precise locations of observation sites are listed in Table 1. The shallow unconfined aquifer in the study area has a thickness of approximately $10-15 \mathrm{~m}$ and a hydraulic conductivity of $1.39-3.9 \mathrm{~m} / \mathrm{d}$. The climate in this region is mainly affected by the monsoon, with an average annual precipitation of $1,155 \mathrm{~mm}$ and annual potential evapotranspiration of $877 \mathrm{~mm}$.

\section{Sampling}

In this study, we mainly focused on the potential influences of landfill leachate and estuarine hydrodynamics (tides) on groundwater quality. To reduce the impact of rainfall and surface water of the river around the study area, field observations were carried out in March 2014, which is a typical dry season. 192 samples were collected from nine sampling sites, including eight groundwater sites and one surface water site. Most selected sampling stations for groundwater were situated near the landfill. Groundwater samples were collected from the shallow unconfined aquifer through observation wells. Surface water samples were collected from a sampling depth of less than $0.3 \mathrm{~m}$ below the water surface. The groundwater table, temperature, $\mathrm{pH}$, salinity, and dissolved oxygen (DO) were all measured in the field using respective probes of $\mathrm{HACH} \mathrm{HQ} 40 \mathrm{~d}$ dual input multi-parameter digital analyzer. To avoid cross-contamination, clean plastic containers were used to draw the water samples from the wells. The samples were stored in sealed containers and transported to the Key Laboratory of Yangtze River Water Environment, Ministry of Education, Tongji University, China. All the samples were acidified with concentrated nitric acid, digested with digiblock S16, and centrifuged at 3,000 rpm for 5 minutes. Supernate was collected and filtered through $0.22 \mu \mathrm{m}$ membrane filters. Heavy metals (including $\mathrm{Cr}, \mathrm{Ni}, \mathrm{Cu}, \mathrm{Zn}, \mathrm{Cd}$, and $\mathrm{Pb}$ ) were measured using an inductively coupled plasma mass spectrometer (ICP-MS). All the chemicals/reagents were analytical grade. Milli-Q ultra-pure water was used throughout the analysis, and all the glassware was properly washed with liquid detergent and rinsed with distilled water before use. 
Table 2. Maximum, minimum, and average values of the measured temperature $\left({ }^{\circ} \mathrm{C}\right), \mathrm{pH}$, salinity $(\mathrm{ng} / \mathrm{L})$, and DO $(\mathrm{mg} / \mathrm{L})$ in March 2014 .

\begin{tabular}{|c|c|c|c|c|c|c|c|c|c|c|}
\hline \multicolumn{2}{|c|}{ Station } & 1 & 2 & 3 & 4 & 5 & 6 & 7 & 8 & $\mathrm{R}$ \\
\hline \multirow{3}{*}{ Temperature } & $\max ^{1}$ & 18.40 & 17.90 & 21.20 & 19.70 & 18.70 & 19.80 & 17.30 & 19.40 & 20.50 \\
\hline & $\min ^{2}$ & 15.40 & 14.00 & 14.00 & 16.20 & 14.70 & 16.00 & 14.50 & 14.90 & 12.10 \\
\hline & $\mathrm{ave}^{3}$ & 16.82 & 15.62 & 16.01 & 18.06 & 16.72 & 17.76 & 16.00 & 16.83 & 16.87 \\
\hline \multirow{3}{*}{$\mathrm{pH}$} & $\max$ & 13.39 & 8.46 & 7.74 & 8.05 & 7.77 & 8.60 & 7.74 & 7.67 & 8.85 \\
\hline & $\min$ & 9.34 & 7.24 & 7.10 & 7.76 & 7.19 & 7.82 & 7.28 & 7.24 & 7.49 \\
\hline & ave & 10.83 & 7.65 & 7.50 & 7.90 & 7.52 & 8.02 & 7.44 & 7.41 & 8.38 \\
\hline \multirow{3}{*}{ Salinity } & $\max$ & 2.00 & 8.00 & 7.00 & 6.00 & 5.00 & 10.00 & 7.00 & 8.00 & 2.00 \\
\hline & $\min$ & 0.50 & 5.00 & 4.00 & 2.00 & 2.00 & 8.00 & 4.00 & 4.00 & 0.50 \\
\hline & ave & 0.73 & 6.19 & 5.81 & 4.85 & 3.92 & 9.38 & 5.31 & 5.77 & 1.06 \\
\hline \multirow{3}{*}{ DO } & $\max$ & 4.17 & 2.88 & 3.13 & 4.06 & 2.78 & 4.98 & 3.76 & 3.56 & 11.97 \\
\hline & $\min$ & 0.85 & 0.63 & 0.51 & 0.89 & 0.97 & 0.45 & 0.76 & 0.83 & 2.09 \\
\hline & ave & 1.92 & 1.07 & 1.33 & 1.94 & 1.46 & 1.36 & 1.40 & 1.43 & 7.22 \\
\hline
\end{tabular}

1: Maximum values, 2: Minimum values, 3: Average values

\section{Analysis Method}

The heavy metal pollutant index (HPI) is based on the work in [19]. It is evaluated by assigning a weight $(W)$ and a sub-index $Q$ for each selected parameter as shown in Eq. (3). The weight is a value between zero and one, reflecting the relative importance of the individual quality considerations. The sub-index is considered according to the ideal value and maximum permitted level of the heavy metal concentrations, which is given in Eq. (4):

$$
\begin{gathered}
H P I=\frac{\sum_{i=1}^{n} W_{i} Q_{i}}{\sum_{i=1}^{n} W_{i}} \\
Q_{i}=\sum_{i=1}^{n} \frac{\left|M_{i}-I_{i}\right|}{S_{i}-I_{i}} \times 1000
\end{gathered}
$$

...where $W_{i}$ is the weight of the $i^{\text {th }}$ heavy metal and $Q_{i}$ is the sub-index of the $i^{\text {th }}$ heavy metal, $n$ is the number of parameters considered, $M_{i}$ is the measured concentration of the $i^{\text {th }}$ heavy metal, $S_{i}$ is the maximum permitted level, and $I_{i}$ is the ideal value of the $i^{t h}$ parameter. Generally, the critical pollution index value is 100 . To make a conservative estimate, quality standard for the first-class groundwater of China (Table 2) is adopted for $I_{i}$ and the third-class groundwater standard used for $S_{i}$. The weights Wi are decided as 0.1 for $\mathrm{Cr}, 0.001$ for $\mathrm{Cu}, 0.00006$ for $\mathrm{Zn}, 0.1$ for $\mathrm{Cd}$, and 0.02 for $\mathrm{Pb}$ referenced to the previous study [20].

The PoS index proposed by Tziritis et al. [21] can be used for performing a comparative assessment of groundwater quality controlled by the same or different factors, which are subjected to the same or different standards and spread over the same or different periods. It serves as an easy-to-implement and unbiased approach for identifying the controlling factors of water quality. The PoS Index is defined as:

$$
\begin{gathered}
P o S=\sum_{j=1}^{m} Q_{f j} \\
Q_{f j}=10^{3} \times\left[\mathrm{M}_{j} \times \mathrm{W}_{j}\right] / \mathrm{S}_{j}
\end{gathered}
$$

$\ldots$ where $M_{j}, W_{j}$ and $S_{j}$ are the measured concentrations,

Table 3. Standard for groundwater quality according to the National Chinese Guidelines $(\mu \mathrm{g} / \mathrm{L})$.

\begin{tabular}{|c|c|c|c|c|c|c|c|}
\hline Classification & $\mathrm{Cr}$ & $\mathrm{Ni}$ & $\mathrm{Cu}$ & $\mathrm{Zn}$ & $\mathrm{Cd}$ & $\mathrm{Pb}$ & Remark \\
\hline First class & 5 & 5 & 10 & 50 & 0.1 & 5 & natural low background value \\
\hline Second class & 10 & 50 & 50 & 500 & 1 & 10 & natural background value \\
\hline Third class & 50 & 50 & 1,000 & 1,000 & 10 & 50 & based on human health \\
\hline Fourth class & 100 & 100 & 1,500 & 5,000 & 10 & 100 & for agriculture and industry \\
\hline Fifth class & 100 & 100 & 1,500 & 5,000 & 10 & 100 & for other use \\
\hline
\end{tabular}


Table 4. Maximum, minimum, and average values of the measured heavy metal concentrations in March 2014.

\begin{tabular}{|c|c|c|c|c|c|c|c|c|c|c|}
\hline \multicolumn{2}{|c|}{ Station } & 1 & 2 & 3 & 4 & 5 & 6 & 7 & 8 & $\mathrm{R}$ \\
\hline \multirow{3}{*}{$\mathrm{Cr}$} & $\max ^{1}$ & 54.07 & 3.49 & 7.51 & 5.13 & 9.03 & 3.64 & 3.01 & 4.47 & 7.72 \\
\hline & $\min ^{2}$ & 2.70 & 0.91 & 1.39 & 1.55 & 5.69 & 1.42 & 0.93 & 1.06 & 0.10 \\
\hline & $\mathrm{ave}^{3}$ & 15.23 & 2.34 & 2.54 & 2.89 & 6.57 & 2.09 & 1.98 & 1.96 & 2.56 \\
\hline \multirow{3}{*}{$\mathrm{Ni}$} & $\max$ & 14.32 & 1.42 & 1.57 & 5.87 & 13.10 & 1.68 & 4.44 & 5.68 & 10.94 \\
\hline & $\min$ & 9.32 & 0.27 & 0.49 & 1.99 & 8.72 & 0.47 & 0.49 & 1.33 & 1.08 \\
\hline & ave & 11.76 & 0.73 & 0.80 & 3.77 & 10.49 & 0.90 & 0.92 & 2.01 & 2.15 \\
\hline \multirow{3}{*}{$\mathrm{Cu}$} & $\max$ & 46.01 & 4.89 & 7.14 & 1.77 & 6.60 & 3.06 & 2.27 & 2.38 & 3.36 \\
\hline & $\min$ & 5.47 & 0.11 & 0.02 & 0.05 & 0.46 & 0.03 & 0.07 & 0.20 & 1.09 \\
\hline & ave & 15.85 & 0.94 & 1.57 & 0.66 & 1.37 & 1.01 & 0.85 & 0.90 & 2.07 \\
\hline \multirow{3}{*}{$\mathrm{Zn}$} & $\max$ & 51.13 & 99.79 & 74.46 & 40.76 & 211.65 & 69.84 & 134.47 & 74.37 & 61.36 \\
\hline & $\min$ & 12.27 & 11.29 & 14.23 & 8.17 & 18.24 & 10.05 & 15.90 & 11.33 & 15.93 \\
\hline & ave & 28.71 & 37.60 & 34.07 & 27.25 & 58.35 & 37.44 & 31.86 & 28.94 & 34.86 \\
\hline \multirow{3}{*}{$\mathrm{Cd}$} & $\max$ & 0.13 & 0.10 & 0.15 & 0.04 & 0.07 & 0.10 & 0.10 & 0.05 & 0.22 \\
\hline & $\min$ & 0.02 & 0.02 & 0.01 & 0.01 & 0.02 & 0.01 & 0.01 & 0.01 & 0.02 \\
\hline & ave & 0.06 & 0.04 & 0.04 & 0.03 & 0.04 & 0.03 & 0.04 & 0.03 & 0.05 \\
\hline \multirow{3}{*}{$\mathrm{Pb}$} & $\max$ & 6.51 & 9.30 & 11.29 & 1.45 & 3.87 & 3.44 & 19.70 & 4.96 & 5.35 \\
\hline & $\min$ & 0.47 & 0.59 & 0.50 & 0.28 & 0.64 & 0.74 & 0.56 & 0.26 & 0.30 \\
\hline & ave & 2.64 & 2.54 & 4.38 & 0.81 & 1.24 & 1.50 & 6.10 & 1.26 & 2.15 \\
\hline
\end{tabular}

1: Maximum values, 2: Minimum values, 3: Average values

the weight, and the maximum permitted level of the $j^{\text {th }}$ heavy metal considered in the PoS index, respectively. The contributions of different pollutants to the PoS Index can be calculated as $Q_{f j} / P o S$.

The classifications of groundwater quality are based on the reference index of $\mathrm{PoS}$, which is calculated by Eqs. (5) and (6) with $M_{j}$ equaling the background concentrations of groundwater in the groundwater quality standard $I_{i}$. Performing the calculations for the reference index of PoS, threshold values are determined, which are subsequently used for the definition of the PoS classes. To make conservative estimations, the first-class standard from the groundwater quality standard of China is adopted for $I_{j}$, and the third-class standard used for $S_{j}$. Table 6

Table 5. The Pearson correlation coefficients $(r)$ between the heavy metal pollutants and other factors in March 2014.

\begin{tabular}{|c|c|c|c|c|c|c|c|c|c|c|c|}
\hline$r$ & Water Table & Temperature & $\mathrm{pH}$ & Salinity & $\mathrm{DO}$ & $\mathrm{Cr}$ & $\mathrm{Ni}$ & $\mathrm{Cu}$ & $\mathrm{Zn}$ & $\mathrm{Cd}$ & $\mathrm{Pb}$ \\
\hline Water Table & 1.00 & -- & -- & -- & -- & -- & -- & -- & -- & -- & -- \\
\hline Temperature & -0.03 & 1.00 & -- & -- & -- & -- & -- & -- & -- & -- & -- \\
\hline $\mathrm{pH}$ & 0.32 & 0.11 & 1.00 & -- & -- & -- & -- & -- & -- & -- & -- \\
\hline Salinity & -0.66 & 0.06 & -0.56 & 1.00 & -- & -- & -- & -- & -- & -- & -- \\
\hline $\mathrm{DO}$ & 0.48 & -0.01 & 0.17 & -0.52 & 1.00 & -- & -- & -- & -- & -- & -- \\
\hline $\mathrm{Cr}$ & 0.34 & 0.07 & 0.69 & -0.46 & 0.00 & 1.00 & -- & -- & -- & -- & -- \\
\hline $\mathrm{Ni}$ & 0.45 & 0.13 & 0.53 & -0.58 & 0.00 & 0.58 & 1.00 & -- & -- & -- & -- \\
\hline $\mathrm{Cu}$ & 0.34 & 0.06 & 0.89 & -0.48 & 0.03 & 0.63 & 0.53 & 1.00 & -- & -- & -- \\
\hline $\mathrm{Zn}$ & -0.14 & -0.13 & -0.22 & 0.08 & -0.01 & -0.03 & 0.20 & -0.09 & 1.00 & -- & - \\
\hline $\mathrm{Cd}$ & 0.11 & 0.03 & 0.39 & -0.40 & 0.23 & 0.14 & 0.24 & 0.44 & 0.03 & 1.00 & - \\
\hline $\mathrm{Pb}$ & 0.10 & -0.27 & -0.09 & 0.01 & -0.08 & -0.09 & -0.21 & 0.00 & -0.02 & 0.20 & 1.00 \\
\hline
\end{tabular}


Table 6. Reference PoS index calculations for groundwater based on the National Chinese Guidelines (Quality Standard for Groundwater, 1994; concentrations are in $\mu \mathrm{g} / \mathrm{L}$ ).

\begin{tabular}{|c|c|c|c|c|c|}
\hline Reference index & $\mathrm{W}_{\mathrm{j}}$ & $\mathrm{M}_{\mathrm{j}}$ & $\mathrm{S}_{\mathrm{j}}$ & $\mathrm{Q}_{\mathrm{fj}}$ & PoS \\
\cline { 1 - 5 } $\mathrm{Cr}$ & 0.13 & 0.01 & 0.05 & 12.50 & \\
\cline { 1 - 5 } $\mathrm{Ni}$ & 0.21 & 0.01 & 0.05 & 20.83 & \multirow{2}{*}{70} \\
\cline { 1 - 5 } $\mathrm{Cd}$ & 0.33 & 0.00 & 0.01 & 3.33 & \\
\cline { 1 - 5 } $\mathrm{Pb}$ & 0.33 & 0.01 & 0.05 & 33.33 & \\
\hline
\end{tabular}

presents the detailed calculations of the reference indices. The classes defined for the PoS Index ranking according to the reference indices are shown in Table 7.

\section{Results and Discussions}

\section{Groundwater Table}

The groundwater table elevation was measured once a day. The elevations are referenced to the Wusong Datum, which is generally used in the Yangtze River delta area. The results for the groundwater table are shown in Fig. 2 , where we see that the groundwater tables varied from $2.65 \mathrm{~m}$ to $3.34 \mathrm{~m}$ in the study area. The groundwater table at Station 1 had a similar temporal variation pattern to that at Station 4, but was about $0.14 \mathrm{~m}$ higher in all of the times. The groundwater table elevations at Station 2 and Station 3 were similar to each other and are approximately $0.2 \mathrm{~m}$ lower on average than that at Station 5. The groundwater table elevations at Station 7 and Station 8 had minor differences. They were approximately $0.6 \mathrm{~m}$ higher than that at Station 6, which is located somewhere between Stations 7 and 8, indicating that the groundwater flow converged near Station 6. Generally, the groundwater table elevations were greater on the western and eastern sides of the landfill and lower in the central part of the study area near the landfill. The area near Station 6 had the lowest groundwater level. This can be more clearly seen in Fig. 3, which delineated the contour of the groundwater table on 25 March 2014. Although the water table was generally lower in the central part of the study area, the locally higher water table at Station 5 may contribute to the leachate dispersion.

The groundwater table in this area was possibly affected by the local topography. As shown in Fig. 4, the ground elevation in the central area was relatively higher than that in the rest of the area. Ground elevations at

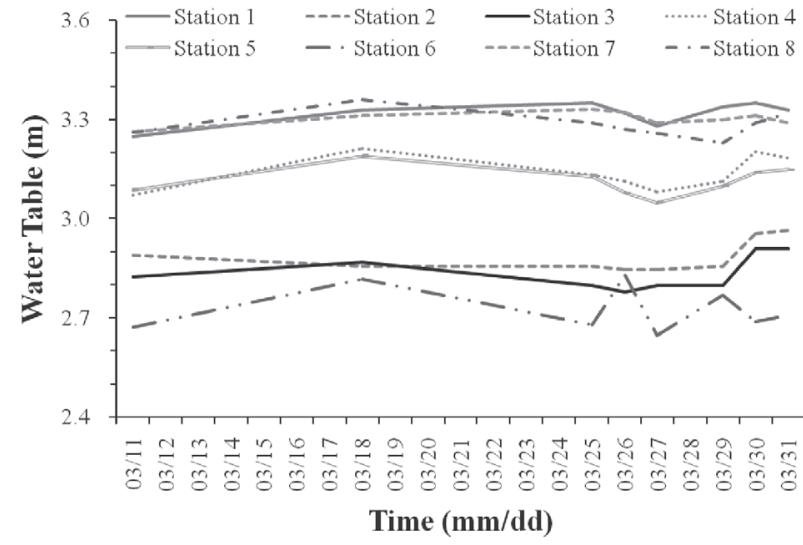

Fig. 2. Groundwater table at eight stations in March 2014.

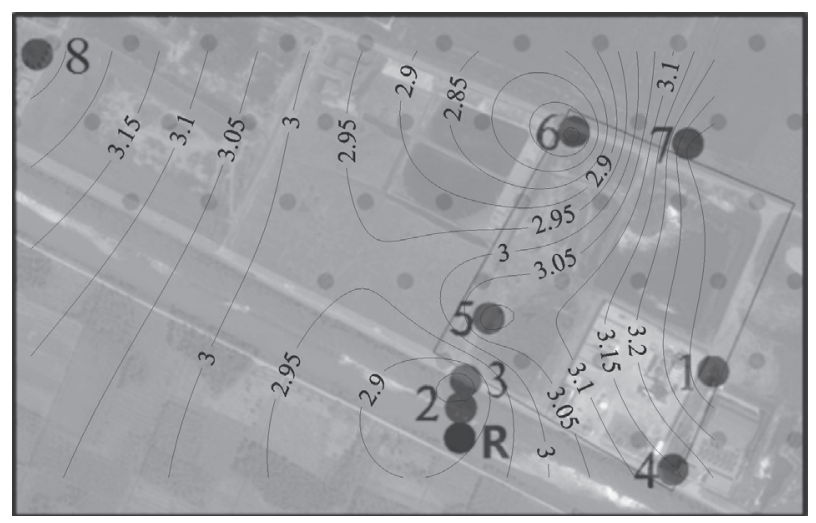

Fig. 3. Contour of the groundwater table on March 25, 2014.

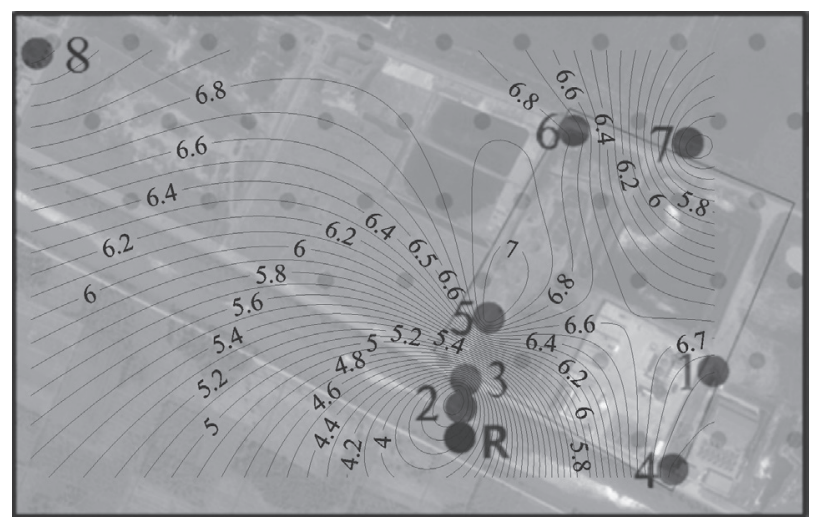

Fig. 4. Ground contours referenced to the Wusong Datum.

Table 7. Groundwater quality classification by PoS Index.

\begin{tabular}{|c|c|c|c|c|c|c|}
\hline Class & 1 & 2 & 3 & 4 & 5 & 6 \\
\hline PoS Index ranges & $<35$ & $35-70$ & $70-105$ & $105-140$ & $140-175$ & $\geq 175$ \\
\hline $\begin{array}{c}\text { Quality } \\
\text { Classification }\end{array}$ & Excellent & Good & $\begin{array}{c}\text { Begin to be } \\
\text { contaminated }\end{array}$ & Lightly polluted & $\begin{array}{c}\text { Moderately } \\
\text { polluted }\end{array}$ & Heavily polluted \\
\hline
\end{tabular}




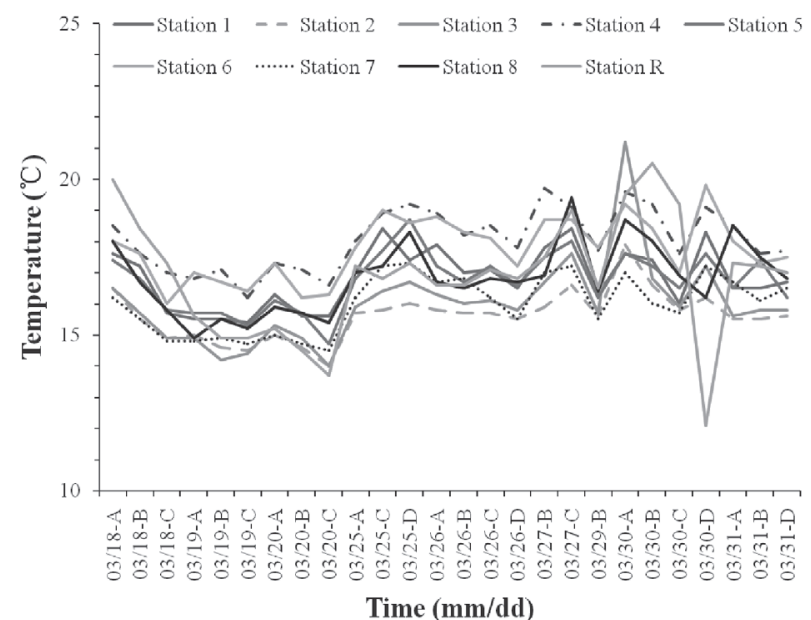

Fig. 5. Measured temperature at nine stations in March 2014.

Stations 2, 3 and 7 were approximately 1.5-2.0 m lower than those at other stations, where the ground elevations were of similar values, and the difference among them was within $0.5 \mathrm{~m}$. This may be the reason that the groundwater table elevations at Stations 1 and 5 are greater than those at the nearby stations. Compared with the water table at Station 3, the relatively higher water table at Station 2 was due to the higher surface water level in a nearby stream. At Stations 7 and 8, the higher water tables may be caused by the water level in the tidal flat area or the nearby pond.

\section{Physico-Chemical Characteristics}

In a groundwater environment, biological and chemical processes are associated with the physical transport and spread of pollutants. As such, physico-chemical characteristics may correlate with pollutant distributions. Therefore, four physico-chemical indices, including temperature, $\mathrm{pH}$, salinity, and DO were measured in field

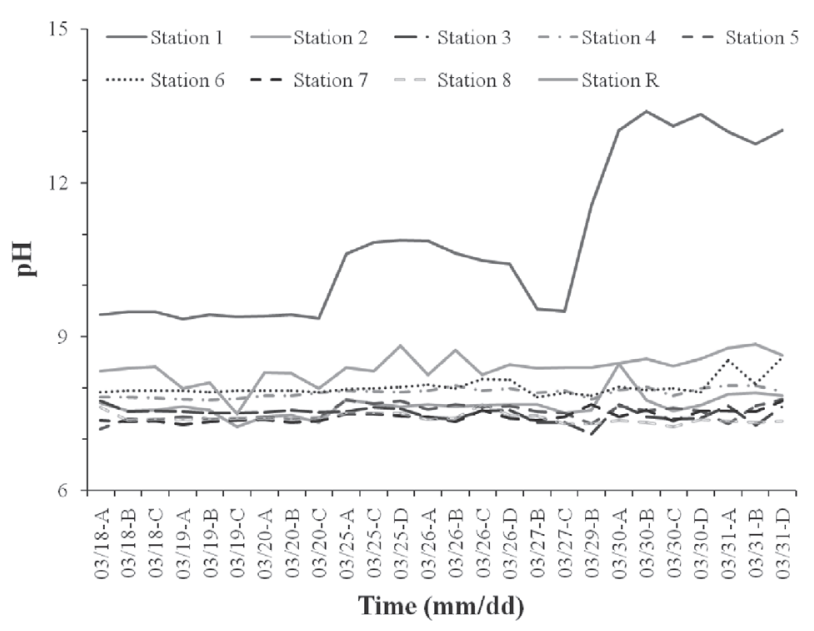

Fig. 6. Measured pH at nine stations in March 2014.

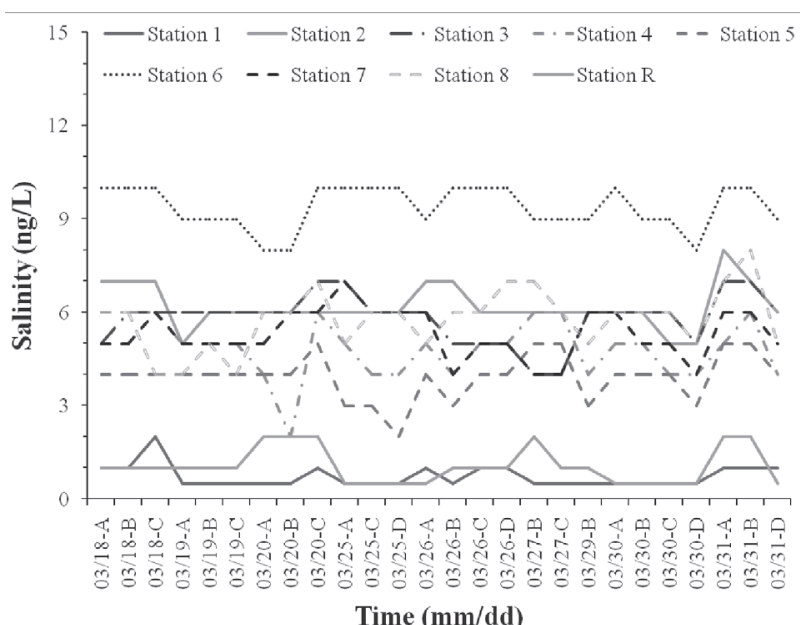

Fig. 7. Measured salinity at nine stations in March 2014.

observations. To analyze the temporal variations of these indices, measurements were carried out three times a day at typical moments of the tide in the Yangtze Estuary. The results are shown in Figs. 5-8, in which A, B, C, and D stand for moments of peak flood, slack tide, peak ebb, and slack tide, respectively, at a hydrological station in the Yangtze Estuary.

Measurement results for temperature are displayed in Fig. 5. The temperatures of the groundwater and surface water had minor differences. The highest temperature of the groundwater was $21.2^{\circ} \mathrm{C}$ at Station 3 and the average value was $16.73^{\circ} \mathrm{C}$. For the surface water, the highest temperature in March was $20.5^{\circ} \mathrm{C}$ and the average value was $16.87^{\circ} \mathrm{C}$. The highest temperatures for the groundwater and surface water both occurred on March 30. There was a decrease in the surface water temperature at the end of March 30, which was not found in the groundwater. Generally, the temperature differences at these stations were insignificant.

Fig. 6 is about the measured $\mathrm{pH}$ values at nine stations. The $\mathrm{pH}$ value was a good indicator of groundwater quality. At most stations (2-8), the $\mathrm{pH}$ values were within the range of 7.5 to 8.5 . Station 1 had a noticeably higher $\mathrm{pH}$ value, with a maximum $\mathrm{pH}$ of 13.39 and an average of 10.83. Station 1 was the closest to the landfill site. The abnormal $\mathrm{pH}$ value was very likely caused by the leachate percolation.

The temporal variations in salinity at these stations are shown in Fig. 7. Due to the saltwater intrusion from the Yangtze Estuary in the dry season, the salinity in this area was generally greater than $4.0 \mathrm{ng} / \mathrm{L}$. The salinity at Station $\mathrm{R}$, which is located in the stream, was relatively low and fell within the range of 0.5 to $2.0 \mathrm{ng} / \mathrm{L}$, with an average value of $1.1 \mathrm{ng} / \mathrm{L}$. The salinity in the groundwater was generally higher than that of the surface water, except at Station 1 where the average salinity was only $0.7 \mathrm{ng} / \mathrm{L}$. The low salinity at this station may be influenced by the freshwater in the nearby pond. The average salinities at Stations 4 and 5 were $4.8 \mathrm{ng} / \mathrm{L}$ and $3.9 \mathrm{ng} / \mathrm{L}$, respectively. At Stations $2,3,7$, and 8 , the maximum salinity was approximately 


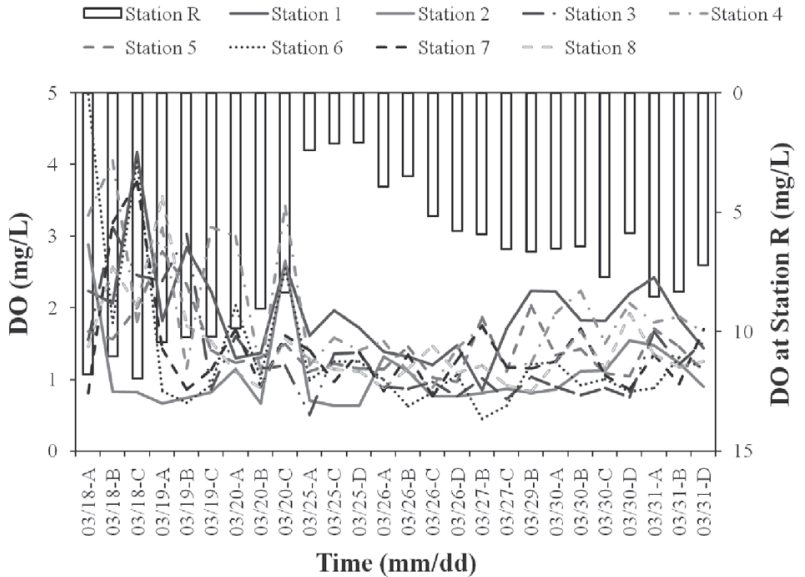

Fig. 8. Measured concentrations of DO at nine stations in March 2014.

7.0-8.0 $\mathrm{ng} / \mathrm{L}$ and the minimum was $4.0-5.0 \mathrm{ng} / \mathrm{L}$. The salinity was extremely high at Station 6 , with an average value of $9.4 \mathrm{ng} / \mathrm{L}$, and the maximum and minimum were $10.0 \mathrm{ng} / \mathrm{L}$ and $8.0 \mathrm{ng} / \mathrm{L}$, respectively. Based on the time series of salinity data, we found that there were three peaks in the salinity distributions for both the ground and surface waters. For the surface water, the peak values occurred on March 20, 27, and 31. The peak values in the groundwater appeared to have some time lags, and it is conjectured that these peaks were related to the spring-neap tide cycle in the Yangtze Estuary.

Fig. 8 shows the variations of DO concentrations in both the ground and surface waters. The DO concentrations varied within the ranges of $0.5-5 \mathrm{mg} / \mathrm{L}$ in the groundwater and $2-12 \mathrm{mg} / \mathrm{L}$ in the surface water. The surface water clearly had higher DO concentrations. In the surface water, the DO concentration showed a decrease from March 18 to March 25, and an increase from then on. The significant fluctuations of DO concentrations in surface water may be influenced by atmospheric conditions. In the groundwater, however, the DO concentrations stayed at relatively constant levels, especially after March 25 . During this period, the DO concentrations at Stations 1 and 4 were slightly higher than those at the other stations. Before March 25, the DO concentrations were relatively high and showed a decreasing trend similar to that in the surface water. The maximum, minimum, and average values of the measured temperature, $\mathrm{pH}$, salinity, and $\mathrm{DO}$ at all of the stations are summarized in Table 2.

\section{Heavy Metal Concentrations and Potential Sources}

To study the distributions of the heavy metal concentrations near the landfill, 192 samples were collected at all nine stations. These samples were analyzed by ICP-MS in the laboratory after proper pre-treatments to obtain the concentrations of $\mathrm{Cr}, \mathrm{Ni}, \mathrm{Cu}, \mathrm{Zn}, \mathrm{Cd}$, and $\mathrm{Pb}$. Trends of the measured heavy metal concentrations were analyzed, and the values were compared with background values according to the national Chinese guidelines (Quality Standard for Groundwater GB/T14848-9) [22]. Classification and standard values for groundwater quality according to the guidelines are shown in Table 3. There are five classes of groundwater quality standards. Concentrations of the first class are adopted here as the natural background value.

The measured concentrations of $\mathrm{Cr}, \mathrm{Ni}, \mathrm{Cu}, \mathrm{Zn}, \mathrm{Cd}$, and $\mathrm{Pb}$ at different times in series are displayed in Figs. 9a-f. As we can see, the highest concentration of $\mathrm{Cr}$ (54.07 $\mu \mathrm{g} / \mathrm{L}$ ) was found at Station 1, which was much greater than the natural background value $(5.0 \mu \mathrm{g} / \mathrm{L})$ according to the quality standards in Table 2 . The $\mathrm{Cr}$ concentration on March 25 at this station had a sudden increase that coincided with the decrease of DO concentration in the surface water. Because Station 1 was the closest to the landfill area, the high concentration of $\mathrm{Cr}$ was clearly a consequence of the landfill disposal. Together with $\mathrm{Cr}$, there may be some other pollutants discharged into the surface water that caused the breeding of aerobic bacteria and resulted in oxygen consumption. The concentration of $\mathrm{Cr}$ at Station 5 was also greater than the background value with an average of $6.57 \mu \mathrm{g} / \mathrm{L}$, while it stayed at a relatively constant level. The average $\mathrm{Cr}$ concentrations at the other stations, including the surface water, were below the background value and fell within the range of 2.0 to $3.0 \mu \mathrm{g} / \mathrm{L}$.

The concentrations of Ni ranged from 0.7 to $11.7 \mu \mathrm{g} / \mathrm{L}$, with $23.5 \%$ of the samples exceeding the background value $(5.0 \mu \mathrm{g} / \mathrm{L})$. Consistent with $\mathrm{Cr}$, the high concentrations of $\mathrm{Ni}$ were also found at Stations 1 and 5, where the Ni concentrations exceeded the background value time during the entire measurement period. At the other stations, the $\mathrm{Ni}$ concentrations were seldom greater than $5.0 \mu \mathrm{g} / \mathrm{L}$.

The $\mathrm{Cu}$ concentrations $>10.0 \mu \mathrm{g} / \mathrm{L}$ (the natural background value) appeared only at Station 1 . We noticed that the high $\mathrm{Cu}$ concentration at Station 1 occurred concurrently with the relatively higher value of $\mathrm{pH}$ on March 30. There was also a sudden increase in the $\mathrm{Cu}$ concentration on March 25 at this station, consistent with the $\mathrm{Cr}$ and $\mathrm{Ni}$ concentrations. At the other stations, the $\mathrm{Cu}$ concentrations were lower than the natural background values. In the surface water, the $\mathrm{Cu}$ concentrations also remained at a low level. There were noticeable fluctuations in the concentrations at Stations 3, 6, and 8, with the concentrations lower than $10.0 \mu \mathrm{g} / \mathrm{L}$.

The $\mathrm{Zn}$ concentrations ranged from $8 \mu \mathrm{g} / \mathrm{L}$ to more than $200 \mu \mathrm{g} / \mathrm{L}$. The concentrations at several stations $(1,2,5$, and 7) exceeded the natural background value of $50 \mu \mathrm{g} / \mathrm{L}$ during certain periods. Surprisingly, Station $5 \mathrm{had}$ the highest concentration of $\mathrm{Zn}$. The sudden increase in the $\mathrm{Zn}$ concentration appeared earlier than those of $\mathrm{Cr}$, and $\mathrm{Ni}$ and happened on March 19. This increase can also be found in the surface water at Station R. Zn-compounds are usually used in timber processing, the paint industry, the textile industry, the paper industry, and in chemical pharmaceuticals, etc. The increase in the $\mathrm{Zn}$ concentration may be caused by wastes in the landfill from the above source. The high concentrations of $\mathrm{Zn}$ may be dispersed 

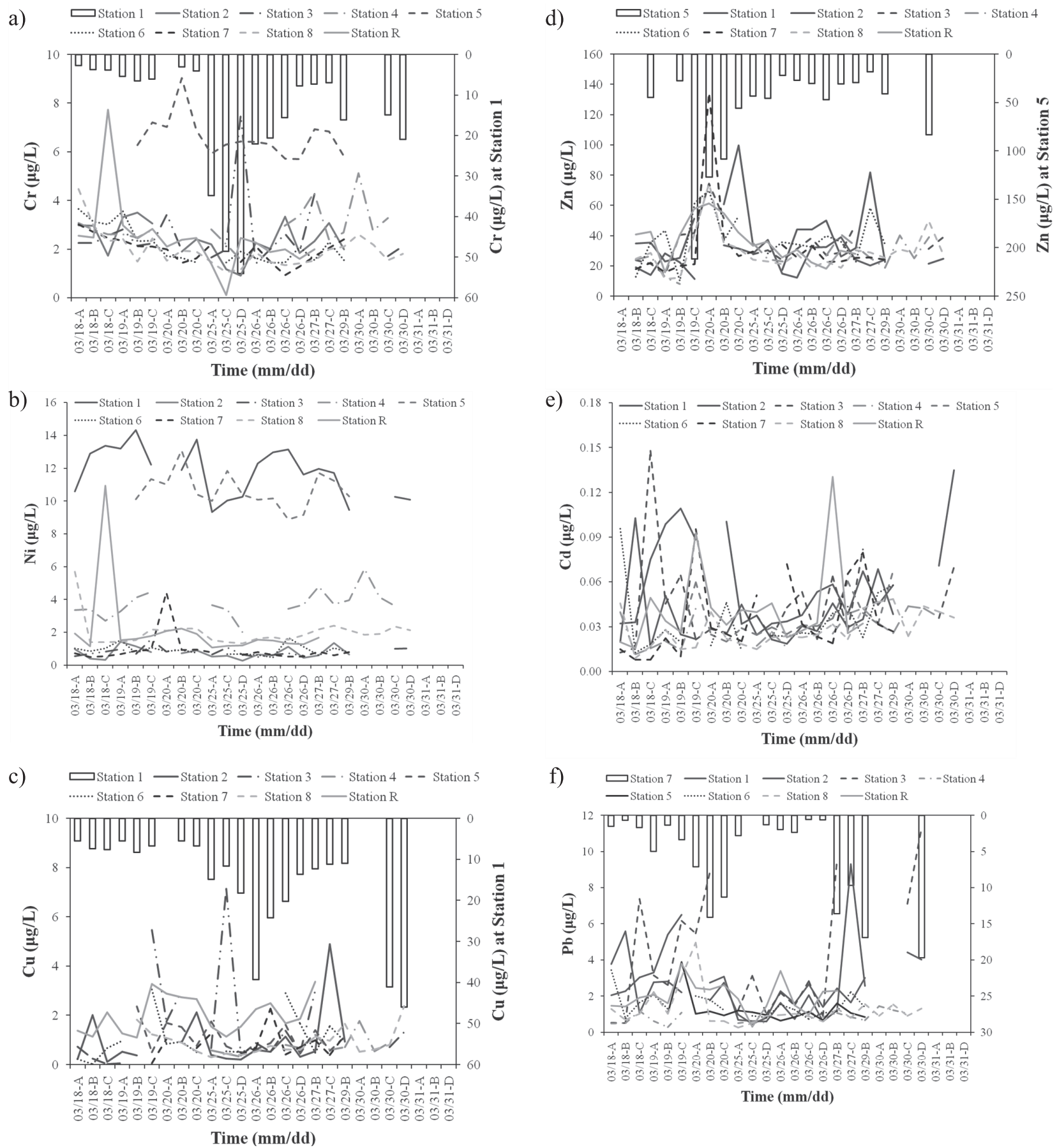

Fig. 9. Measured concentrations of heavy metals at nine stations in March 2014: a) Cr concentration time series, b) Ni concentration time series, c) $\mathrm{Cu}$ concentration time series, d) $\mathrm{Zn}$ concentration time series, e) $\mathrm{Cd}$ concentration time series, $\mathrm{f}$ ) $\mathrm{Pb}$ concentration time series.

to the other stations because of the relatively high groundwater table at Station 5.

The concentrations of $\mathrm{Cd}$ and $\mathrm{Pb}$ are also shown in Fig. 9. The average concentrations of $\mathrm{Cd}$ and $\mathrm{Pb}$ were very low, which were $0.04 \mu \mathrm{g} / \mathrm{L}$ and $2.51 \mu \mathrm{g} / \mathrm{L}$, respectively. The Cd concentrations of some samples at Stations 1 and 3 exceeded the natural background value of $0.1 \mu \mathrm{g} / \mathrm{L}$. The $\mathrm{Pb}$ concentrations were greater than the natural background value $(5.0 \mu \mathrm{g} / \mathrm{L})$ at Stations $1,2,3$, and 7 . The high $\mathrm{Pb}$ concentrations occurred mostly at Station 7 , which is the nearest station to the tidal flat in the northern branch of the Yangtze Estuary. We can also find three peaks in the $\mathrm{Pb}$ concentrations at Station 7 on March 20, March 27, and March 30, consistent with the distribution of salinity. Hence, it is believed that the $\mathrm{Pb}$ concentrations may be affected by the tidal dynamics in the Yangtze Estuary.

From the above analysis, we conclude that both the landfill and estuarine dynamics (tides) play an important role in the distribution of the heavy metal concentrations in the study area. Table 4 shows the maximum, minimum, 
and average values of the measured heavy metal concentrations in March 2014. The concentrations of $\mathrm{Cr}, \mathrm{Ni}, \mathrm{Cu}$, and $\mathrm{Cd}$ were higher at Station 1, which was possibly affected by the landfill disposal. The concentration of $\mathrm{Pb}$ was higher at Station 7 and it may be affected by the estuarine hydrodynamics or the water quality in the Yangtze Estuary.

\section{Correlations between Heavy Metal Concentrations and Physico-Chemical Properties}

The Pearson correlation coefficient [23] is widely used to measure the dependence between two quantities. It could be obtained by dividing the covariance of the two variables or two series of data by the product of their standard deviations. The Pearson correlation coefficient is a useful index in aerography, biology, and pollution assessment. It is selected to reveal the relationship between the heavy metal concentrations and physicochemical properties (i.e., temperature, $\mathrm{pH}$, salinity, and DO) of groundwater.

The Pearson correlation coefficients $(r)$ between heavy metal pollutants and physico-chemical properties were calculated as shown in Table 5. High correlations among $\mathrm{Cr}, \mathrm{Ni}$, and $\mathrm{Cu}$ were observed with correlation coefficients greater than 0.53 , which is consistent with the findings of Abdel-Salam and Abu-Zuid [24]. This means that these three heavy metal pollutants have the same source, i.e.,
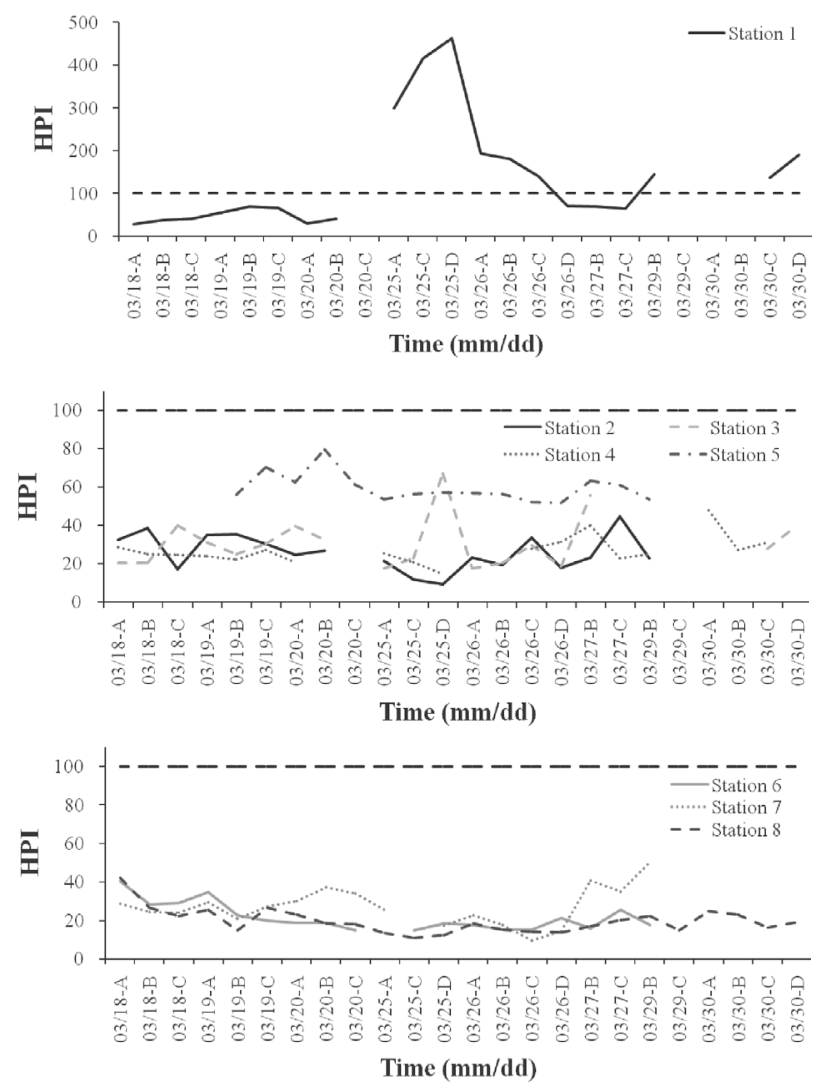

Fig. 10. Time series of HPI at eight stations in March 2014 (the dashed line is the critical value for HPI).

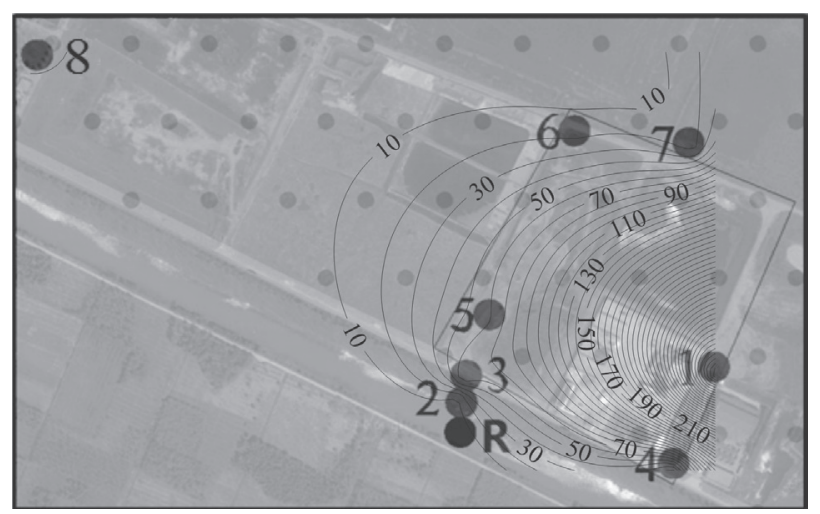

Fig. 11. Contour of the HPI index in the study area on March 25 (slack water) 2014.

the landfill. High correlations were also found between heavy metal pollutants $(\mathrm{Cr}, \mathrm{Ni}$, and $\mathrm{Cu})$ and physicochemical properties ( $\mathrm{pH}$ and salinity). This confirms that the heavy metal concentrations in the study area were greatly affected by both of the landfill and the tides in the Yangtze Estuary. As mentioned above, the $\mathrm{pH}$ value was indicative of leachate percolation. When the $\mathrm{pH}$ was accidentally high, high concentrations of heavy metals were also observed [25].

Salinity is mainly influenced by saltwater intrusion from the Yangtze Estuary, which is usually severe in
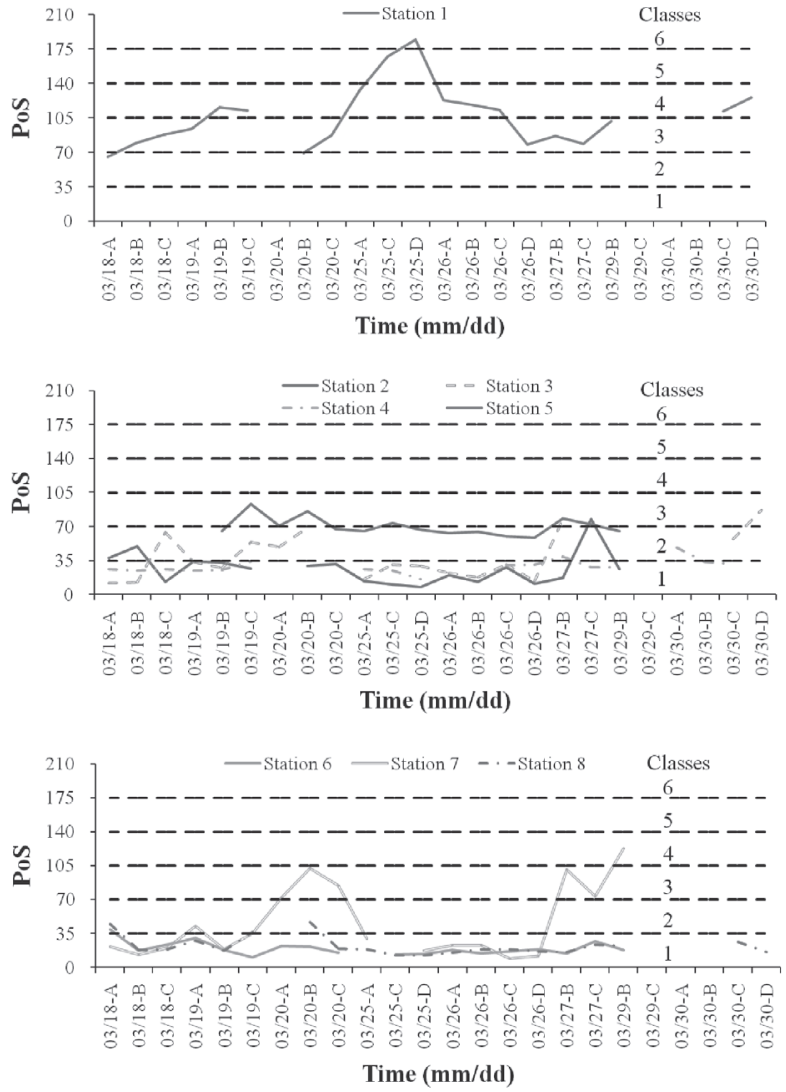

Fig. 12. Time series of the PoS index at eight stations in March 2014 (the dashed lines are the critical values for the PoS Index). 


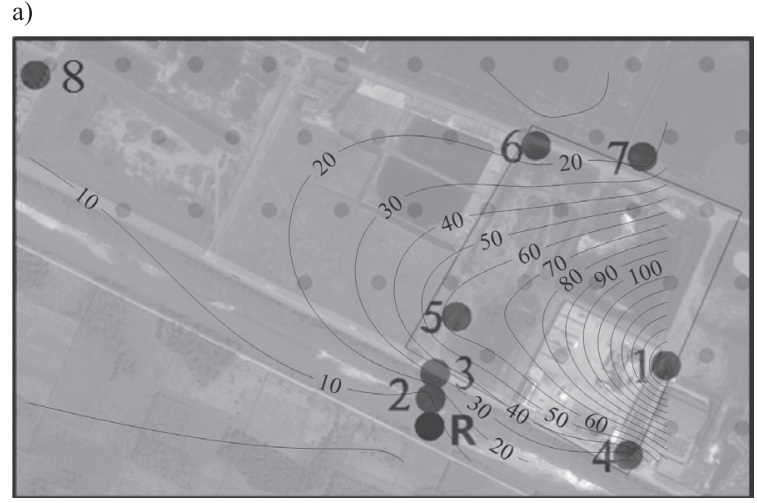

b)

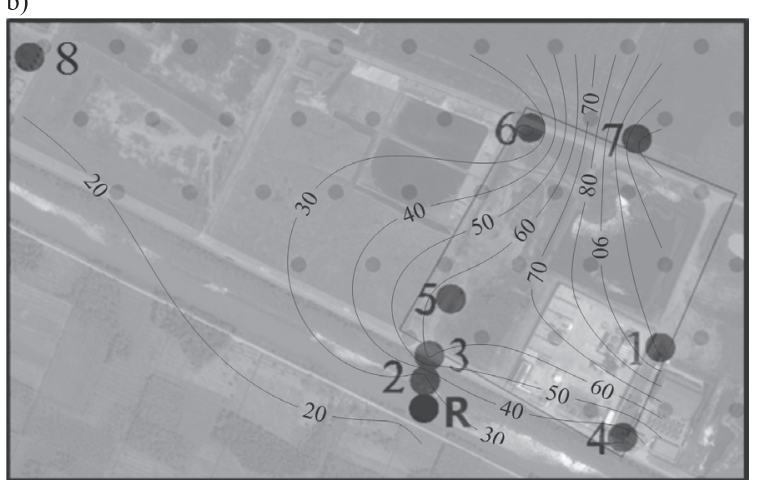

Fig. 13. Contour of the PoS Index in the study area: a) contour of the PoS Index on March 25 (slack water) 2014, b) contour of the PoS Index on March 29 (slack water) 2014.

the dry season, especially in the northern branch of the estuary. This can be confirmed by the high correlation between salinity and the water table. When the water table was low, the saltwater intrusion occurred more easily. After the saltwater intrusion occurs, the water table would be slightly higher with the fluctuations of heavy metal concentrations. There have some time lags between these processes, which could explain the negative correlations between the heavy metal concentrations and salinity, and between salinity and the water table. The correlation between $\mathrm{Pb}$ and salinity was extremely low because the concentration of $\mathrm{Pb}$ varies significantly over time. However, the coincidence of the peaks of these two variables clearly showed the correlation as discussed before. The heavy metal concentrations had poor correlations with temperature and DO, indicating that these two parameters were not the dominant factors affecting the distribution of the heavy metal concentrations.

\section{Groundwater Quality Assessment Using Pollution Index Methods}

The HPIs were calculated using the time series data of heavy metal concentrations $(\mathrm{Cr}, \mathrm{Cu}, \mathrm{Zn}, \mathrm{Cd}$, and $\mathrm{Pb}$ ) at eight groundwater stations, which are demonstrated in Fig. 10. The results have shown that the HPIs were below critical value (100) at all stations except No. 1, where the HPIs were $390,145,144$, and 163 on March
$25,26,29$, and 30 , indicating that the area near this station had very poor groundwater quality during these periods. The pattern of the HPI variation at this station was quite similar to that of the $\mathrm{Cr}$ concentrations (Fig. 9a), indicating that the high HPIs were mostly influenced by $\mathrm{Cr}$. The HPI at Station 5 was relatively large. The HPI indices were higher than 50 on most days of the survey period. The HPI at Station 7 was greater than 50 by the end of March. These three stations were the closest to the landfill. The groundwater quality at these three stations was generally worse than those at other stations. To illustrate the spatial distributions of the HPI index, we plotted the HPI contour on March 25, when Station 1 became polluted and had the highest HPI. Fig. 11 has clearly shown that the HPI value was concentrated at Station 1 and decreased along all directions. At Station 8, which was the farthest from Station 1, the HPI was very low, indicating excellent groundwater quality and revealing that contamination was restricted to the landfill area.

The PoS Indices were calculated using the time series data of the heavy metal concentrations $(\mathrm{Cr}, \mathrm{Ni}, \mathrm{Cd}$, and $\mathrm{Pb}$ ) at all of the stations, which are demonstrated in Fig. 12. The results have shown that the PoS Index was always below 70 (groundwater quality worse than class-2) at Stations 2, 3, 4, 6, and 8. The groundwater quality at these five stations was good and sometimes excellent, consistent with the HPI analysis. This was because Stations 6 and 8 were far away from the center of the landfill, and Stations 2, 3 and 4 were close to the stream with relatively clean water. At Station 7, the PoS Index was generally lower than 70, indicating good groundwater quality. However, it fell into Class 3 and Class 4 on March 20 and 27, respectively. Then it reached 123 on March 29 and 142 on March 30, with water qualities falling into Class 4 and Class 5, respectively. The groundwater at this station was severely contaminated during these periods. The results of measurement illustrated that the groundwater quality became worse at the end of March near Station 7. Compared with the measured time series data of the heavy metal concentrations shown in Fig. 9, only the $\mathrm{Pb}$ concentrations at Station 7 increased at the end of March, which demonstrates that the high PoS Index at this station might be mostly attributed to the $\mathrm{Pb}$ concentrations. At Station 5, the PoS Index was greater than 70 on March 19, 20, 25, and 27, with groundwater qualities in Class 3. According to the PoS Index, the most serious pollution occurred at Station 1, where the PoS Index was always higher than 70. Peaks in the PoS Index appeared on March 19, 25, and 30, with groundwater qualities falling into Class 4, Class 6, and Class 4, respectively. The PoS Index analysis was generally consistent with the HPI index analysis.

Figs 13(a-b) have presented the contour plots of the PoS Index on March 25 and 29 (both in slack water moment), respectively. It can be observed that the distributions of the PoS Indices on these two days were quite similar. They were also consistent with the distributions of the HPI indices as shown in Fig. 11. The high PoS 
Index values appeared again near Station 1. On March 25 the PoS Index at Station 7 was low. As groundwater quality in this area was mainly controlled by landfill disposal, groundwater at Stations 1 and 5 were the most severely polluted. On March 29, however, the PoS Index at Station 7 was high, which was mainly caused by $\mathrm{Pb}$ pollution. Based on the time series and correlation analyses, the $\mathrm{Pb}$ pollution was related to saltwater intrusion from the Yangtze Estuary. As the HPI index, the PoS Index also decreased from the west to the east.

\section{Conclusions}

In this study, field observations were carried out in March 2014 to assess the groundwater quality and analyze the impact factors of groundwater in a shallow aquifer around a landfill disposal site at a coastal area on Chongming Island, Shanghai, China. Based on time series analysis and correlation analysis, the distributions of the groundwater table, the physico-chemical properties of groundwater, heavy metal concentrations $(\mathrm{Cr}, \mathrm{Ni}, \mathrm{Cu}$, $\mathrm{Zn}, \mathrm{Cd}$, and $\mathrm{Pb}$ ), and potential sources of heavy metals were all discussed. In addition, the groundwater quality was assessed through a combination of the heavy metal pollution index (HPI) and the PoS Index.

The results have shown that the relatively high water table appeared underneath the landfill site (Stations 1 and 5), where the heavy metal concentrations were also high. In general, $\mathrm{Cd}$ and $\mathrm{Pb}$ were in very low concentrations in this area, while concentrations of $\mathrm{Cr}$ and $\mathrm{Zn}$ were slightly higher than the background values. Strong correlations were found between the heavy metal $(\mathrm{Cr}, \mathrm{Ni}$, and $\mathrm{Cu}$ ) concentrations and the physico-chemical properties (salinity and $\mathrm{pH}$ ), indicating that both the landfill and the tides played an important role in the transportation of the heavy metals. Near the disposal site, both the HPI and PoS Indices were greater than the critical values, indicating that this area had been polluted by heavy metals. Particularly, around Station 1 located close to the landfill site, the groundwater had been severely polluted by heavy metals. $\mathrm{Cr}$ and $\mathrm{Ni}$ were the major heavy metals causing the groundwater contamination. Occasionally, $\mathrm{Pb}$ resulting from the saltwater intrusion from the estuary may pollute some areas near the landfill.

\section{Acknowledgements}

This work was sponsored by the Shanghai Pujiang Program (15PJ1408200) and the National Natural Science Foundation of China (NSFC 41602244 and 41672230). The authors also acknowledge the support of NSFC 41372240, NSFC-RFBR 41611130047, and the Fundamental Research Funds for the Central Universities of China (2014KJ010).

\section{References}

1. ALLEYW.M., HEALY R.W., LABAUGH J.W., REILLY T.E. Flow and storage in groundwater systems. Science, 296, (5575), 1985, 2002.

2. YANG Q.C., WANG L.C., MA H.Y., YU K., MARTIN J.D. Hydrochemical characterization and pollution sources identification of groundwater in Salawusu aquifer system of Ordos Basin, China. Environmental Pollution, 216, 340, 2016.

3. ECONOMOU-ELIOPOULOS M., FREI R., ATSAROU C. Application of chromium stable isotopes to the evaluation of $\mathrm{Cr}(\mathrm{VI})$ contamination in groundwater and rock leachates from central Euboea and the Assopos basin (Greece). Catena, 122, 216, 2014.

4. BAUMANN T., FRUHSTORFER P., KLEIN T., NIESSNER R. Colloid and heavy metal transport at landfill sites in direct contact with groundwater. Water Research, 40, 2776, 2006.

5. MUHAMMAD S., SHAH M., KHAN S. Health risk assessment of heavy metals and their source apportionment in drinking water of Kohistan region, northern Pakistan. Microchemical Journal, 98, 334, 2011.

6. PHAN K., PHAN S., HUOY L., SUY B., WONG M., HASHIM J., YASIN M., ALJUNID S., STHIANNOPKAO S., KIM K. Assessing mixed trace elements in groundwater and their health risk of residents living in the Mekong River basin of Cambodia. Environmental Pollution, 182, 111, 2013.

7. LEUNG C., JIAO J. Heavy metal and trace element distributions in groundwater in natural slopes and highly urbanized spaces in Mid-Levels area, Hong Kong. Water Research, 40, 753, 2006

8. GRIFT B., GRIFFIOEN J. Modelling assessment of regional groundwater contamination due to historic smelter emissions of heavy metals. Journal of Contaminant Hydrology, 96, 48, 2008.

9. VISSER A., KROES J., VLIET M., BLENKINSOP S., FOWLER H., BROERS H. Climate change impacts on the leaching of a heavy metal contamination in a small lowland catchment. Journal of Contaminant Hydrology, 127, 47, 2012.

10. ZHANG T., WEI H., YANG X., XIA B., LIU J., SU C., QIU R. Influence of the selective EDTA derivative phenyldiaminetetraacetic acid on the speciation and extraction of heavy metals from a contaminated soil. Chemosphere, 109, 1, 2014.

11. DEVIC G., DJORDJEVIC D., SAKAN S. Natural and anthropogenic factors affecting the groundwater quality in Serbia. Science of the Total Environment, 468-469, 933, 2014.

12. MASOUD A. Groundwater quality assessment of the shallow aquifers west of the Nile Delta (Egypt) using multivariate statistical and geostatistical techniques. Journal of African Earth Sciences, 95, 123, 2014.

13. ZHANG B., SONG X., ZHANG Y., HAN D., TANG C., YU Y., MA Y. Hydrochemical characteristics and water quality assessment of surface water and groundwater in Songnen plain, Northeast China. water research, 46, 2737, 2012.

14. PATHAK D., HIRATSUKA A. An integrated GIS based fuzzy pattern recognition model to compute groundwater vulnerability index for decision making. Journal of Hydroenvironment Research, 5, 63, 2011. 
15. YIDANA S., BANOENG-YAKUBO B., AKABZA T.M. Analysis of groundwater quality using multivariate and spatial analyses in the Keta basin, Ghana. Journal of African Earth Sciences, 58, 220, 2010.

16. MOHEBBI M., SAEEDI R., MONTAZERI A., VAGHEFI K., LABBAFI S., OKTAIE S., ABTAHI M., MOHAGHEGHIAN A. Assessment of water quality in groundwater resources of Iran using a modified drinking water quality index (DWQI). Ecological Indicators, 30, 28, 2013.

17. STIGTER T.Y., RIBEIRO L., DILL C. Application of a groundwater quality index as an assessment and communication tool in agro-environmental policies-Two Portuguese case studies. Journal of Hydrology, 327, 578, 2006.

18. RAPANT S., KORDIK J. An environmental risk assessment map of the Slovak Republic: application of data from geochemical atlases. Environmental Geology, 44, 400, 2003.

19. MOHAN S.V., NITHILA P., and REDDY S.J. Estimation of heavy metal in drinking water and development of heavy metal pollution index. Journal of Environmental Science and
Health. Part A: Environmental Science and Engineering and Toxicology, 31 (2), 283, 1996.

20. PRASAD B., SANGITA K. Heavy Metal Pollution Index of Ground Water of an Abandoned Open Cast Mine Filled with Fly Ash: a Case Study. Mine Water Environ, 27, 265, 2008.

21. TZIRITIS E., PANAGOPOULOS A., ARAMPATZIS G. Development of an operational index of water quality (PoS) as a versatile tool to assist groundwater resources management and strategic planning. Journal of Hydrology, 517, 339, 2014.

22. Quality Standard for Groundwater, National Chinese guidelines, GB/T 14848-9, 1994 [In Chinese]

23. PEARSON K. On lines and planes of closest fit to systems of points in space. Philos. Mag. 2, 559, 1901.

24. ABDEL-SALAM M., ABU-ZUID G. Impact of landfill leachate on the groundwater quality: A case study in Egypt. Journal of Advanced Research, 6(4), 579, 2014.

25. SUZUKI K., WAKI M., YASUDA T., FUKUMOTO Y., KURODA K., SAKAI T., SUZUKI N., SUZUKI R., MATSUBA K. Distribution of phosphorus, coppend zinc in activated sludge treatment process of swine wastewater. Bioresource Technology, 101, 9399, 2010. 
